\title{
Study on Geochemical Characteristics and Depositional Environment of Pengcuolin Chert, Southern Tibet
}

\author{
He Junguo, Zhou Yongzhang \& Li Hongzhong \\ Dept. of Earth Sciences, Center for Earth Environment \& Resources \\ Zhongshan University, Guangzhou 510275, China \\ E-mail: eeshjg@mail.sysu.edu.cn; eeszhouyz@mail.sysu.edu.cn; lihongzhong01@126.com
}

Received: June 23, 2011 Accepted: July 7, 2011 doi:10.5539/jgg.v3n1p178

\begin{abstract}
Based on the field investigations and analysis on major elements, trace elements and rare earth elements, the Geochemical Characteristics and Depositional Environment of Pengcuolin Chert are studied.The massive chert is green and brown in colour, has high $\mathrm{SiO}_{2}$ content and locally enrich $\mathrm{Fe}$ and $\mathrm{Mn}, \mathrm{Al} /(\mathrm{Al}+\mathrm{Fe}+\mathrm{Mn})$ ratio is lower, in Fe-Mn-Al triangle diagrams, most samples fall into hydrothermal region, trace elements such as $\mathrm{Sr}, \mathrm{Zr}, \mathrm{Cu}, \mathrm{Zn}$ and $\mathrm{Ba}$ are higher and $\Sigma \mathrm{REE}$ is lower, with Ce negative anomaly and Eu anomaly. Their NASC-normalized REE distribution patterns are slightly left-leaning, which indicate that the chert is hydrothermal origin. In environment discrimination diagram such as $100 \times \mathrm{Fe}_{2} \mathrm{O}_{3} / \mathrm{SiO}_{2}-100 \times \mathrm{Al}_{2} \mathrm{O}_{3} / \mathrm{SiO}_{2}, \mathrm{Fe}_{2} \mathrm{O}_{3} /\left(100-\mathrm{SiO}_{2}\right)-\mathrm{Al}_{2} \mathrm{O}_{3} /\left(100-\mathrm{SiO}_{2}\right)$ and $\mathrm{Fe}_{2} \mathrm{O}_{3} / \mathrm{TiO}_{2}-\mathrm{Al}_{2} \mathrm{O}_{3} /\left(\mathrm{Al}_{2} \mathrm{O}_{3}+\mathrm{Fe}_{2} \mathrm{O}_{3}\right)$, most chert samples fall into the areas of mid-ocean ridges or deep-sea. In parameter variation diagrams, samples of PCL-5 and PCL-7 are much closer to the hydrothermal center. It is shown that the Pengcuolin chert, southern Tibet was formed by the hydrothermal systems at convergence and subduction sites of plates.
\end{abstract}

Keywords: Chert, Geochemistry, Hydrothermal sedimentation, Mid-ocean ridge, Douthern Tibet, Pengcuolin

\section{Introduction}

Chert, one kind of chemical and biochemical sedimentations, is widely distributed in the orogenic belts, it is the ore-bearing rocks and source beds of many deposits(Cui Chunlong, 2001; Feng Caixia and Liu Jiajun, 2001), chert has the quality of high hardness and strong resistance to weathering, which make it hard to be deformed by the late geological processes and a lot of diagenetic information can be well preserved in it, so chert are commonly used to study the palaeotopography and palaeosedimentary environment(Yang Haisheng et al., 2003). Recently, with the development of testing equipment, approaches studying chert is getting advanced, apart from some traditional methods on the rock occurrence, structure and textural characteristics, mineral contents and geochemical analysis, some advanced techniques such as UV fluorescence, CL and paleomagnetism are applied to study chert, and now more attentions are paid to to the origin, the source and the sedimentary environment of chert (Yang Zhijun et al., 2003).

Systematic field investigations show that chert in southern Tibet develop large scale distribution, is of different ages, various sedimentary formations and deposit in sea and continent sedimentary settings, this offer an ideal place for systematic chert study and so have absorbed many attentions of this field both from home and abroad in recent years (Wang Dongan and Chen Ruijun, 1995; Zhou Yongzhang et al., 2003,2004,2006; Sun Lixin et al., 2004; Zhu Jie et al., 2005; Ren Yunsheng et al.,2005; He Junguo et al., 2007).

\section{Geological settings and petrologic characteristics}

Pengcuolin chert profile, 30 kilometers north away form Lazi county, Xikaze, consist mainly of chert, basalt and ultramafic rocks(Fig.1), Tectonically, it sandwiched between the Himalayan and the Lhasa blocks, abundant tectonic melange and high-pressure $\mathrm{m}$ Cambrian as tectonic slices, or emplaced in the Upper Triassic Xiukang Group as well as Upper Jurassic- Lower Cretaceous flyschoid and radiolarian chert.

The chert section contain sequences of chert, basalt and ultramafic rocks, with layered chert developing on the top of the formation, and conformable contacting with the altered basalt in the bottom, showing green and purple color, with the thickness of a few centimeters to tens of meters (Fig.2A). Great deal of brown massive chert are identified, which display grey to brown color, probably due to the local Fe, Me mineralization (Fig 2B). 
The chert is mainly composed of authigenic quartz (sometimes more than 90\%), chalcedony and opals, and with some calcite, clay minerals, beldongrites and hematites. Fe, Mn mineralization can be clearly observed on the hand specimen (Fig 2C), under microscope, samples are dominated by aphanic-microcrystalline quartz grains (Fig. 2D). chert display different colors, this may due to the constituents contained in the chert, among them, black chert always are rich in organic maternal, red and purple chert often related with hematite, while green chert result from the addition of some ferrichlorite and mixed layer minerals.

\section{Sampling and analysis}

7 specimens are sampled in Pengcuolin profile, experiments are carried out by the Key Isotope Laboratory, Guangzhou Institute of Geochemistry, Chinese Academy of Sciences. The test process are as follows: first select the samples, and then clean the surface of the rock to remove the weathering layers and impurities, and then are ground into pieces, choose the fresh grains and washed by distilled water for decontamination, and finally are ground to above 200 mesh, dried and preserved. press disk (XRF) is used to measure major elements $\mathrm{SiO}_{2}$, other contents are tested by Inductively coupled plasma emission spectrometry (ICP-AES), with the analytical errors $<2 \%$. ICP-AES and ICP- MS test solution are prepared by acid solution, the detailed process is: accurately weigh $100 \mathrm{mg}$ samples and placed in the sealed Teflon, add $1 \mathrm{ml}$ concentrated HF and $0.3 \mathrm{ml} 1: 1$ of HNO3, put on the $150{ }^{\circ} \mathrm{C}$ heating plate to dry the samples after ultrasonic vibration, and then add equal amounts of $\mathrm{HF}$ and $\mathrm{HNO}_{3}$, sealed and heated for one week $\left(\right.$ about $\left.100^{\circ} \mathrm{C}\right)$, then dissolved in $2 \mathrm{ml} \mathrm{1:} 1 \mathrm{HNO}_{3}$, adding $\mathrm{Rh}$ internal standard, and then dilute to 2000 times, finally analysed by ICP-MS of PE Elan 6000. the results are shown as Table 1.

\section{Geochemical characteristics and sedimentary environment of chert}

\subsection{Major elements}

Pengcuolin chert contain great amounts of $\mathrm{SiO}_{2}$, with the average of $75.3 \%$, ranging from $62.05 \%$ to $93.64 \%$, and there is an increasing trend from the bottom to the top, while $\mathrm{Al}_{2} \mathrm{O}_{3}$, averaging $5 \%$, vary greatly from $1.23 \%$ to $11.59 \%$, such as sample PCL-5 and PCL-6, being $6.84 \%$ and $11.59 \%$ respectively. For the content of $\mathrm{TiO}_{2}$, changing between $0.01 \%$ and $0.63 \%$, with the average of $0.23 \%$. Previous studies demonstrate that some major elements such as $\mathrm{Fe}, \mathrm{Mn}$ and $\mathrm{Al}$ play a basic role in identifying the origin of chert (Yang Haisheng et al., 2003; Zhang Fan et al., 2003), contents of Fe and $\mathrm{Mn}$ are associated with hydrothermal sedimentation, while $\mathrm{Al}$ is related with terrigenous supply. Based on the researches of hydrothermal and biological sedimentation, Adachi (Adachi $\mathrm{M}$ et al., 1986) and Yamamoto(Yamamoto $\mathrm{K}, 1987)$ pointed out that the ratios of $\mathrm{Al} /(\mathrm{Fe}+\mathrm{Mn}+\mathrm{Al})$ change from 0.01 for hydrothermal origin to 0.60 for biological sedimentation, and the ratios are getting larger with increasing the distance from the hydrothermal system center(Lei Bianjun et al., 2002). In the studied area, $\mathrm{Al} /(\mathrm{Al}+\mathrm{Fe}+\mathrm{Mn}$ ) value is $0.08-0.59$, averaging 0.32 (Table 2), all samples, except PCL-6, plot in the hydrothermal area(Fig 3d). The $\mathrm{Al} /(\mathrm{Fe}+\mathrm{Mn}+\mathrm{Al})$ variations are showed in Fig 4, three minimum values can be observed, indicating that there may be three sedimentations which are near the hydrothermal vent in Pengcuolin profile (Fig. 4).

$\mathrm{MnO}$ content in chert stand for the deep ocean hydrothermal sedimentation and $\mathrm{TiO}_{2}$ is related with terrigenous material, so the ratio $\mathrm{MnO} / \mathrm{TiO}_{2}$ can be used to judge the paleosedimentary environment of chert (Murray RW, 1994). For the chert occurring in the open ocean environment, $\mathrm{MnO} / \mathrm{TiO}_{2}>0.5$, while for continental slope and marginal sea deposits, $\mathrm{MnO} / \mathrm{TiO}_{2}<0.5$, the ratios of Pengcuolin chert are generally higher, being 2.7-76.1, with average of 21.8 (Table 2), indicating that the chert are formed in ocean ridges and deep basins environments. In addition, ratio of $\mathrm{Al}_{2} \mathrm{O}_{3} /\left(\mathrm{Al}_{2} \mathrm{O}_{3}+\mathrm{Fe}_{2} \mathrm{O}_{3}\right)$ can also be used to identify the sedimentary environment of chert (Sugitani, $\mathrm{K}$ et al., 1996), the ratios $\mathrm{Al}_{2} \mathrm{O}_{3} /\left(\mathrm{Al}_{2} \mathrm{O}_{3}+\mathrm{Fe}_{2} \mathrm{O}_{3}\right)$ for studied area is between 0.18 and 0.17 , with the average 0.41 (Table 4), closing to the ratio of ocean ridge.

Murray have mapped the continental margin, ocean basin and ocean ridge projection areas of siliceous rocks based on the sedimentary environment ratios of known chert (Murray R W and Buchholtz M R, 1977), in 100× $\mathrm{Fe}_{2} \mathrm{O}_{3} / \mathrm{SiO}_{2}-100 \times \mathrm{Al}_{2} \mathrm{O}_{3} / \mathrm{SiO}_{2}$ diagrams (Table 3, Fig.3a), all samples, except PCL-6, fall in ocean ridge areas, while in $\mathrm{Fe}_{2} \mathrm{O}_{3} /\left(100-\mathrm{SiO}_{2}\right)-\mathrm{Al}_{2} \mathrm{O}_{3} /\left(100-\mathrm{SiO}_{2}\right)$ diagrams, all samples plot near the ocean ridge and ocean basin areas ( Table 3, Fig 3b), and all samples, except PCL-4, fall in mid ocean and ocean basins in the $\mathrm{Fe}_{2} \mathrm{O}_{3} /$ $\mathrm{TiO}_{2}-\mathrm{Al}_{2} \mathrm{O}_{3} /\left(\mathrm{Al}_{2} \mathrm{O}_{3}+\mathrm{Fe}_{2} \mathrm{O}_{3}\right)$ diagram (Table 3, Fig 3c).

\subsection{Rare earth elements}

Rare earth element can be a good geochemical tracer for study the chert origin, plaeoocean environment as well as the oxidation and reduction conditions (Shimizu H M A, 1977; Ding Lin and Zhong Dalai, 1995), the REE of chert mainly derive from seawater, and some come from the continental and volcanic scraps. It is believed that there is an increasing trend of $\sum$ REE from median ridge (the minimum $1.09 \times 10^{-6}$ ), ocean basin to continental 
margin(Murray, R. W et al., 1991). For Pengcuolin chert, all samples except PCL-5 and PCL-7, have low $\sum$ REE, with the average of $77.7 \mathrm{ppm}$ (Table 4,5), general lower than the normal values $(>200 \mathrm{ppm}$ ), which indicate that the chert originate from the thermal water and a little terrigenous contents addition during the diagenetic process. The North American shale normalized pattern shows HREE enrichment, the REE distribution pattern slightly tilted to the left, showing the characteristics of hydrothermal chert (Fig.5), among them, sample PCL-7 display higher $\sum$ REE, possible because of some $\sum$ REE-rich hydatogen sediments mixed during the sedimentation process.

According to Shimizu and Masuda (1991), Deep Sea Drilling Plan(DSDP) indicate that Ce/ Ce* values of chert vary from 0.29 to 0.467 (Shimizu H M A, 1977), in the areas near median ridges, due to the hydrothermal activities, negative anomaly is increasing and HREE were strongly depleted compared to LREE (Elderfield, $\mathrm{H}$ and Upstill Goddard, R., 1990), such as the sedimentation occurring in the Eastern Pacific, $\mathrm{Ce} / \mathrm{Ce}$ * range from 0.1 to 0.36 . for Pengcuolin chert, $\mathrm{Ce} / \mathrm{Ce}^{*}$ vary from 0.32 to 1.15 , with the average of 0.85 (Table 5), and most samples show negative anomaly, especially two samples PCL-7 and PCL-5, the $\mathrm{Ce} / \mathrm{Ce}$ * values are much lower, being 0.32 and 0.4 , respectively (Fig 6-a), indicating that the profile is closer to the ocean ridge. In addition, a few samples (PCL-4) show weak negative anomaly or even positive anomaly, this possible because there are some $\mathrm{Fe}, \mathrm{Mn}$ minerals mixed in the samples, which is consistent with the fact that $\mathrm{Fe}$ and $\mathrm{Mn}$ mineralization can be observed on the hand specimen (Fig 2c). In oxidation ocean environment, $\mathrm{Ce}^{3+}$ can be oxidated into lower solubility $\mathrm{Ce}^{4+}$, which can isomorphic displace $\mathrm{Mn}^{4+}$ and inter iron and manganese oxides crystalline cells, this migration may result in the Ce negative abnormality in the sea and $\mathrm{Ce}$ positive abnormality in the ferromagnesian minerals. It can be concluded that chert only inherit the Ce negative abnormally if hydrothermal sediments are separated with ferromagnesian minerals, and show Ce weak negative abnormality even positive abnormality if the two mixed together.

After studying the cherts occurring in the areas $75 \mathrm{~km}$ away from the mid-ocean ridges, Murray suggested that the $\mathrm{Eu} / \mathrm{Eu}^{*}$ values decrease from 1.35 to 1.02 (Murray, R.W et al., 1990), and Eu positive anomaly is the characteristic of hydrothermal sedimentation. For studied chert, $\mathrm{Eu} / \mathrm{Eu}^{*}$ is $0.81-1.05$, being positive anomaly, indicating the hydrothermal sedimentary characteristics (Table5, Fig.6-b), in addition, some other REE ratios such as $(\mathrm{La} / \mathrm{Ce})_{\mathrm{N}}$ and $(\mathrm{La} / \mathrm{Lu})_{\mathrm{N}}$ can also be used to infer the sedimentary mechanism of chert (Wang Zhonggang, 1992), chert occurring in continental margins, ocean basins and ridges have different $(\mathrm{La} / \mathrm{Ce})_{\mathrm{N}}$ values, among them, chert near the ocean ridges are strongly depleted $\mathrm{Ce}$, with $(\mathrm{La} / \mathrm{Ce})_{\mathrm{N}}$ being 3.5 , while chert for ocean basins is $2-3$, and chert for continental margins is about 1 . For Pengcuolin chert, $(\mathrm{La} / \mathrm{Ce})_{\mathrm{N}}$ vary greatly, ranging from 0.8-3.55, with the average of 1.49(Fig 6-e, Table 5). According to Murray RW, parameter $(\mathrm{La} / \mathrm{Lu})_{\mathrm{N}}$ or $(\mathrm{La} / \mathrm{Yb})_{\mathrm{N}}$ can indicate the separation degree between LREE and HREE, he pointed out that $(\mathrm{La} / \mathrm{Lu})_{\mathrm{N}}$ from 0.65 of ocean ridge increase to 1.15 of $85 \mathrm{~km}$ away from the ocean ridge, and to the maximum 2.70 in the ocean basin(Murray $\mathrm{RW}, 1994)$. For Pengcuolin chert, $(\mathrm{La} / \mathrm{Lu})_{\mathrm{N}}$ is $0.53-1.65$, averaging 0.95 (Table 5), indicating that the chert deposit in the ocean ridge sedimentary environment.

The REE variation curves show that obvious Ce/ Ce* abnormity in position PCL-5 and PCL-7 can be seen (Fig 5, Fig 6-a)and there are large LREE /HREE separate degree in position PCL-5and PCL-7 (Fig.6-d), moreover, $(\mathrm{La} / \mathrm{Ce})_{\mathrm{N}}$ values also show similar features (Fig. 6-e), implying that the sample locations PCL-5 and PCL-7 may close to the hydrothermal center, this results are consistent with the discussions of major elements (Fig.4).

\subsection{Trace elements}

Many scholars have studied the trace element geochemistries of chert (Murray, R. W et al., 1990; Zhou Yongzhang, 1990; Zhao Zhenhua, 1997), Previous studies show that higher amount of Ba, As, Sb, Ag, B and U are characteristic of hydrothermal sedimentation, modern hot sediments generally enrich $\mathrm{Cu}, \mathrm{Ni}$, and deplete $\mathrm{Co}$, $\mathrm{Ni} /$ Co ratio $<3.6$ (Crerar, D. A et al,1982). Pengcuolin chert have little amount of V, $\mathrm{Rb}$ and $\mathrm{Sr}$, less than 10 percent of the Clarke value (Table 4), while $\mathrm{Zn}, \mathrm{Pb}, \mathrm{Zn}, \mathrm{Ba}, \mathrm{Cu}, \mathrm{Cr}$ and $\mathrm{Ni}$ vary greatly and positive correlated with major element $\mathrm{Fe}$ and $\mathrm{Mn}$. It can be seen From the spider net of trace element that chert has high $\mathrm{Mn}, \mathrm{Ti}$ contents, reaching 7779 and 3103 ppm, respectively (Fig 7, Table 4), among them, high amount Ti is because of the input of terrigenous sediments, and higher $\mathrm{Mn}$ due to the coprecipitation of $\mathrm{Mn}$ and chert, this phenomenon can also be seen on the Fe, Mn mineralization of hand specimen (Fig 2C). The spider net (Fig 2C) demonstrate that Pengcuolin chert enrich $\mathrm{Sr}, \mathrm{Zr}, \mathrm{Cu}, \mathrm{Zn}$ and $\mathrm{Ba}, \mathrm{Ni} / \mathrm{Co}$ is 1.08-3.16, averaging 1.84, less than 3.6 (Table 4), indicating that the chert is of hydrothermal origin.

\subsection{Discussion}

Geochemical characteristics of chert show that the studied chert is of typical hydrothermal features, among them, for major element, chert have lower $\mathrm{Al} /(\mathrm{Al}+\mathrm{Fe}+\mathrm{Mn})$ values, averaging 0.32, and most samples plot in the 
hydrothermal area in $\mathrm{Al} /(\mathrm{Al}+\mathrm{Fe}+\mathrm{Mn})$ diagram, trace elements such as $\mathrm{Sr}, \mathrm{Zr}, \mathrm{Cu}, \mathrm{Zn}$ and $\mathrm{Ba}$ contents are higher, $\mathrm{Ni} / \mathrm{Co}<3.6$, while $\sum \mathrm{REE}$ contents are lower, with $\mathrm{Ce} / \mathrm{Ce}^{*}$ abnormity and $\mathrm{Eu} / \mathrm{Eu}^{*}$ positive abnormality, exhibiting the hydrothermal characteristics.

According to previous studies, the stable property of chert can be used to identify the sedimentary environment(Cui Chunlong, 2001; Lei Bianjun et al.,2002; Yang Haisheng et al., 2003), the analysis results show that Pengcuolin chert are formed in big oceanic ridges and ocean basin surroundings.

So, it is concluded that since Mesozoic, when Tethys from open to close, with the oceanic crust spreading, material overflow from the depth, and magmas eruptions of seafloor take place, during this process, Ultramafic, mafic rocks and a variety of volcanic lava are formed, at the same time, due to the strong friction, pressure reduction and deformation of plates are caused by the plate convergence and subduction, oceanic hydrothermal system is produced around the ridges and hot point of seafloor, forming a geochemical areas favorable for silica enrichment, preservation, contraction and saturation, and then silica precipitate constantly from Jurassic to Cretaceous, thus forming the sick chert formation.

\section{Conclusions}

(1) For Pengcuolion chert, $\mathrm{SiO}_{2}$ contents vary greatly, ranging from $62.05 \%$ to $93.64 \%$, with the average of $75.3 \%$, and tends to increase from the bottom to the top.

(2) $\mathrm{Al} /(\mathrm{Al}+\mathrm{Fe}+\mathrm{Mn})$ values for chert are lower, averaging 0.32 , most samples fall into the hydrothermal district in $\mathrm{Fe}-\mathrm{Mn}-\mathrm{Al}$ triangle diagrams; trace elements $\mathrm{Sr}, \mathrm{Zr}, \mathrm{Cu}, \mathrm{Zn}$ and $\mathrm{Ba}$ are higher, $\mathrm{Ni} / \mathrm{Co}$ is 1.08-3.16, less than 3.6; $\sum$ REE are lower, averaging $77.7 \mathrm{ppm}, \mathrm{Ce} / \mathrm{Ce}^{*}$ (averaging 0.85 ) show negative abnormality, Eu/ $\mathrm{Eu}^{*}(0.81-1.05)$ is positive anomaly, $(\mathrm{La} / \mathrm{Ce})_{\mathrm{N}}$ and $(\mathrm{La} / \mathrm{Lu})_{\mathrm{N}}$ is 1.49 and 0.95 , respectively. Major, trace elements and REE all show hydrothermal characteristics, indicating that the chert is of hydrothermal origin.

(3) $\mathrm{MnO} / \mathrm{TiO}_{2}$ is $21.8, \mathrm{Al}_{2} \mathrm{O}_{3} /\left(\mathrm{Al}_{2} \mathrm{O}_{3}+\mathrm{Fe}_{2} \mathrm{O}_{3}\right)$ is 0.41 , in diagram $100 \times \mathrm{Fe}_{2} \mathrm{O}_{3} / \mathrm{SiO}_{2}-100 \times \mathrm{Al}_{2} \mathrm{O}_{3} / \mathrm{SiO}_{2}, \mathrm{Fe}_{2} \mathrm{O}_{3} /$ $\left(100-\mathrm{SiO}_{2}\right)-\mathrm{Al}_{2} \mathrm{O}_{3} /\left(100-\mathrm{SiO}_{2}\right)$ and $\mathrm{Fe}_{2} \mathrm{O}_{3} / \mathrm{TiO}_{2}-\mathrm{Al}_{2} \mathrm{O}_{3} /\left(\mathrm{Al}_{2} \mathrm{O}_{3}+\mathrm{Fe}_{2} \mathrm{O}_{3}\right)$, all samples fall into or near the ocean ridge and deep sea areas, implying that the chert are formed in the ocean ridge or deep sea basin environment.

(4) Major elements and REE variations Ce/Ce*, LREE /HREE and $(\mathrm{La} / \mathrm{Ce})_{\mathrm{N}}$ show that sample location PCL-5 and PCL-7 may close to the hydrothermal center.

\section{Acknowledgement}

This study was supported by the National Key Basic Research Program (No.2006CB4035008) and the National Natural Science Foundation of China (No.40573019). The author thank Prof. Li Jingao, Geological Survey of Tibet, for his help during the field investigations, thanks are also due to Prof. Liuying and Mr. Tu Xianglin, Guangzhou Institute of Geochemistry, Chinese Academy of Sciences, for their assistance during the sample testing.

etamorphic rocks are identified, with the related volcano- magmatic arc zones in the north, ophiolite and melange developing in the south. the ophiolite melange mainly include ophiolithe, upper Triassic-lower Cretaceous sedimentary melange and J-K ophiolite melange, which are pushed on the Precambrian gneiss and schist, and quartz schist of

\section{References}

Adachi, M., Yamamoto, K. \& Suigiski, R. (1986). Hydrothermal chert and associated siliceous rocks from the Northern Pacific: their geological significance a sindication of ocean ridge activity. Sedimentary Geology, 47, 125-148. doi:10.1016/0037-0738(86)90075-8, http://dx.doi.org/10.1016/0037-0738(86)90075-8

Crerar, D. A., Namson, J. \& Chyi, M. S. (1982). Manganiferous chert of the Franciscan assemblage: I. General geology ancient and modern analogues and implications for hydrothermal convection at oceanic spreading centers. Econ. Geol, 77(3), 519-540. doi:10.2113/gsecongeo.77.3.519, http://dx.doi.org/10.2113/gsecongeo.77.3.519

Cui, Chunlong. (2001). Some Problems in the Study of Siliceous Rocks. Journal of Mineralogy and Petrology, 21 (3), 100-104.

Ding, Lin., \& Zhong, Dalai. (1995). Characteristics of Rare Earth Elements and Ce Abnormality in Old Tethys of Chang Ning-Meng Lian, West Yunnan. Science in China, Ser,B Earth Sciences, 1, 93-100.

Elderfield, H. \& Upstill Goddard, R. (1990). The rare earth elements in rivers, estuaries and coastal sea waters and their significance to the composition of sea water. Geochimica et Cosmochimica Acta, 54, 971-991. doi:10.1016/0016-7037(90)90432-K, http://dx.doi.org/10.1016/0016-7037(90)90432-K 
Feng, Caixia \& Liu, Jiajun. (2001). The Investive Actuslity and Mineralization Significance of Cherts. World geology, 20(2), 119-123.

He, Junguo, Zhou, Yongzhang, \& Nie, Fengjun. (2007). Petrologic and Geochemical Characteristics of the Hydrothermal Chert in Southern Tibet and Its Geological Significance. Bulletin of Mineralogy, Petrology and Geochemistry, 26(1), 74-81.

Lei, Bianjun, Que, Hongpei. \& Hu Ning. (2002). Geochemistry And Sedimentary Environments of the Palaeozoic Siliceous Rocks in Western Hubei. Sedimentary Geology And Tethyan Geology, 22(2), 70-79.

Murray, R. W. \& Buchholtz, M. R. (1992). Rare earth, major,and trace element composition of Monterey and DSDP chert and associated host sediment: assessing the influence of chemical fractionation during diagenesis. Geochimica et Cosmochimica Acta, 56(7), 2657-2671. doi:10.1016/0016-7037(92)90351-I, http://dx.doi.org/10.1016/0016-7037(92)90351-I

Murray, R. W. (1994). Chemical criteria to identify the depositional environment of chert: general principles and Application. Sedimentary Geology, 90, 213-232. doi:10.1016/0037-0738(94)90039-6, http://dx.doi.org/10.1016/0037-0738(94)90039-6

Murray, R. W., Buchholtz Ten Brink., M. R. \& Gerlach, D. C. (1991). Rare earth, major and trace elements in chert from the Franciscan Complex and Monterey Group, California: Assessing REE sources to finegrained marine sediments. Geochimica et Cosmochimica Acta, 55(7), 1875-1895. doi:10.1016/0016-7037(91)90030-9, http://dx.doi.org/10.1016/0016-7037(91)90030-9

Murray, R. W., Jones, D. L., Gerlach, D. C. \& Russ, G. P. (1990). Rare Earth Elements as Indicators of Different Marine Depositional Environments in Chert and Shale. Geology, 18(3), 268-271. doi:10.1130/0091-7613(1990)018<0268:REEAIO $>2.3 . C O ; 2$,

http://dx.doi.org/10.1130/0091-7613(1990)018<0268:REEAIO $>2.3 . C O ; 2$

Ren, Yunsheng., Su, Dengkui., \& Zhang, Jinshu. (2002). Superimposted mineralization of gold in Jiama copper polymentallic deposit, Tibet. Journal of Jilin University: Earth Science Edition, 32 (3), 225-228.

Shimizu, H. M. A. (1977). Cerium in chert as an indication of marine envrionment of its formation. Nature, 266, 348- 364. doi:10.1038/266346a0, http://dx.doi.org/10.1038/266346a0

Sugitani, K., Horiuchi, Y., Adachi, M., \& Sugisaki, R. (1996). Anomalously low Al2O3/TiO2 values for Archean cherts from the Pilbara Block, Western Australia--possible evidence for extensive chemical weathering on the early earth. Precambrian Research, 80(1-2), 49-76. doi:10.1016/S0301-9268(96)00005-8, http://dx.doi.org/10.1016/S0301-9268(96)00005-8

Sun, Lixin, Wan, Xiaoqiao, \& Jia, Jiancheng. (2004). Sedimentary Environments of Siliceous Rock in the Western Yarlung Zangbo Suture Zone, SouthernTibet. Acta Geological Sinica, 78 (3), 380-389.

Wan, Xiaoqiao, Li, Guobiao \& Si, Jialiang. (2003). The distribution and ages of Late Cretaceous-Paleocene oceanic red beds in southern Tibet. Earth Science Frontiers, 12(2), 31-37.

Wang Dongan \& Chen Ryujun. (1995). Geochemical Genetic Criteria of Silicolites In Yaluzangbu Suture Belt And Their Geological Significance. Acta Sedimentologica Sinica, 13(1), 27-31.

Wang Zhonggang. (1992). Rare earth element geochemistry. Beijing: Geological Publishing House.

Yamamoto, K. (1987). Geochimical characteristics and depositional environments of cherts and associated rocks in the Franciscan and Shimanto terrenes. Sedimentary Geology, 52, 65-108. doi:10.1016/0037-0738(87)90017-0, http://dx.doi.org/10.1016/0037-0738(87)90017-0

Yang Haisheng, Zhou Yongzhang., \& Yang Zhijun. (2003). REE Geochemical Characteristics of Hydrothermal Cherts from South China. Bulletin of Mineralogy, Petrology and Geochemistry, 22(1), 61-64.

Yang, Haisheng, Zhou, Yongzhang. \& Yang, Zhijun. (2003). Geochemical Characteristics and Significance of Hydrothermal Cherts-A Case Study of South China. Acta Scientiarum Naturalium Universitas Sunyatseni, 42(6), 111-115.

Yang, Zhijun, Zhou, Yongzhang \& Zhang, Chengbo. (2003). The Research of Fabric Information in the Siliceous Rock and Its Significance. Bulletin of Mineralogy, Petrology and Geochemistry, 22(3), 255-258.

Zhang, Fan, Feng, Qinglai \& Zhang, Zhibin. (2003). Caracteristics and paleogeographic significance of Early Carboniferous Cherts at the Nongba Section in the Gengma Area, Southwestern Yunan. Geological Bulletin of China, 22 (5), 335-340. 
Zhao, Zhenhua. (1997). Trace element geochemistry principle. Beijing: Science Press.

Zhou, Yongzhang, Fu, Wei \& Yang, Zhijun. (2006). Microfabrics of Cherts from YArlung Zangbo Sture Zone and southern Tibet And its Geological Implication. Acta Petrologica Sinica, 22(3), 742-750.

Zhou, Yongzhang, Yang, Zhijun \& Li, Wen. (2003). Primaiy study on the cherts from Tibet[C]//China Institute of Mineralogy,Petrology and Geochemistry of the North Annual Conference Essays. Guiyang: [s.n.], 43.

Zhou, Yongzhang, Yang, Zhijun \& Nie, Fengjun,. (2004). Characteristics and Significances of Mesozonic-Cenozonic ophiolite chert and non- ophiolite Chert in Southern Tibet. Bulletin of Mineralogy, Petrology and Geochemistr, 198-200.

Zhou, Yongzhang. (1990). On Sedimentary Geochemistery of cherts Originated from Thermal Water in Nandan-He chi Basin. Acta Sedimentologica Sinica, 3, 75-83.

Zhu, Jie, Du, Yuansheng \& Liu, Zaoxue.( 2005). Genesis and Geotectonic Significance of Mesozoic Radiation Cherts from Middle Part of Yarlung Zangbo Sutrue ,Tibet. Science in China Ser, D Earth Sciences, 35(12), 1131-1139.

Table 1. Major contents of Pengcuolin cherts (w/\%)

\begin{tabular}{|c|c|c|c|c|c|c|c|c|c|c|}
\hline sample & $\mathrm{SiO}_{2}$ & $\mathrm{Al}_{2} \mathrm{O}_{3}$ & $\mathrm{CaO}$ & $\mathrm{Fe}_{2} \mathrm{O}_{3}$ & $\mathrm{~K}_{2} \mathrm{O}$ & $\mathrm{MgO}$ & $\mathrm{MnO}$ & $\mathrm{Na}_{2} \mathrm{O}$ & $\mathrm{P}_{2} \mathrm{O}_{5}$ & $\mathrm{TiO}_{2}$ \\
\hline PCL-1 & 93.64 & 1.23 & 0.88 & 3.02 & 0.32 & 0.09 & 0.20 & 0.31 & 0.03 & 0.07 \\
\hline PCL-2 & 80.83 & 6.14 & 1.08 & 5.40 & 0.13 & 0.57 & 0.94 & 3.17 & 0.08 & 0.29 \\
\hline PCL-3 & 88.64 & 4.19 & 0.58 & 3.17 & 0.05 & 0.10 & 0.51 & 1.84 & 0.04 & 0.15 \\
\hline PCL-4 & 87.53 & 3.46 & 1.65 & 5.10 & 0.01 & 0.81 & 0.61 & 0.11 & 0.01 & 0.01 \\
\hline PCL-5 & 51.22 & 6.84 & 0.97 & 31.56 & 1.43 & 0.63 & 1.69 & 2.44 & 0.19 & 0.63 \\
\hline PCL-6 & 63.16 & 11.59 & 6.06 & 4.62 & 0.05 & 3.21 & 1.27 & 6.55 & 0.11 & 0.37 \\
\hline PCL-7 & 62.05 & 1.55 & 7.30 & 5.60 & 0.60 & 0.90 & 7.76 & 0.28 & 9.84 & 0.10 \\
\hline average & 75.3 & 5.00 & 2.65 & 8.36 & 0.37 & 0.90 & 1.85 & 2.10 & 1.47 & 0.23 \\
\hline
\end{tabular}

Table 2. Major element ratios of Pengcuolin cherts

\begin{tabular}{|c|c|c|c|c|c|c|}
\hline sample & $\mathrm{Al} /(\mathrm{Al}+\mathrm{Fe}+\mathrm{Mn})$ & $\mathrm{Fe} / \mathrm{Ti}$ & $(\mathrm{Fe}+\mathrm{Mn}) / \mathrm{Ti}$ & $\mathrm{Fe}_{2} \mathrm{O}_{3} / \mathrm{TiO}_{2}$ & $\mathrm{MnO} / \mathrm{TiO}_{2}$ & $\mathrm{Al}_{2} \mathrm{O}_{3} /\left(\mathrm{Al}_{2} \mathrm{O}_{3}+\mathrm{Fe}_{2} \mathrm{O}_{3}\right)$ \\
\hline PCL-1 & 0.22 & 52.8 & 56.8 & 44.2 & 2.88 & 0.29 \\
\hline PCL-2 & 0.42 & 22.2 & 26.53 & 18.5 & 3.23 & 0.53 \\
\hline PCL-3 & 0.46 & 24.7 & 29.1 & 20.8 & 3.33 & 0.57 \\
\hline PCL-4 & 0.31 & 595 & 673 & 510 & 61 & 0.4 \\
\hline PCL-5 & 0.13 & 58.2 & 61.6 & 50.4 & 2.71 & 0.18 \\
\hline PCL-6 & 0.59 & 14.7 & 19.1 & 12.5 & 3.45 & 0.71 \\
\hline PCL-7 & 0.08 & 65.3 & 165.5 & 55 & 76.1 & 0.22 \\
\hline average & 0.32 & 119 & 147.4 & 101.63 & 21.81 & 0.41 \\
\hline
\end{tabular}

Table 3. Major ratios for environment discrimination of cherts

\begin{tabular}{|c|c|c|c|c|c|c|c|c|}
\hline sample & BCL-1 & BCL-2 & BCL-3 & BCL-4 & BCL-5 & BCL-6 & BCL-7 & average \\
\hline $100 \times \mathrm{Fe} 2 \mathrm{O} 3 / \mathrm{SiO} 2$ & 3.23 & 6.7 & 3.6 & 5.8 & 61.6 & 7.3 & 9 & 13.89 \\
\hline $100 \times \mathrm{AL} 2 \mathrm{O} 3 / \mathrm{SiO} 2$ & 1.3 & 7.6 & 4.7 & 3.95 & 13.4 & 18.4 & 2.5 & 7.41 \\
\hline $\mathrm{Fe} 2 \mathrm{O} 3 /(100-\mathrm{SiO} 2)$ & 0.47 & 0.28 & 0.28 & 0.41 & 0.65 & 0.13 & 0.15 & 0.34 \\
\hline $\mathrm{A} 2 \mathrm{O} 3 /(100-\mathrm{SiO} 2)$ & 0.19 & 0.32 & 0.37 & 0.28 & 0.14 & 0.31 & 0.04 & 0.24 \\
\hline
\end{tabular}


Table 4. REE and trace element contents of Pengcuolin cherts

\begin{tabular}{|c|c|c|c|c|c|c|c|c|c|c|c|c|c|c|c|c|c|c|c|c|}
\hline T C & $\mathrm{Ti}$ & $\mathrm{V}$ & $\mathrm{Cr}$ & $\mathrm{Mn}$ & Co & $\mathrm{Ni}$ & $\mathrm{Cu}$ & $\mathrm{Zn}$ & $\mathrm{Ga}$ & $\mathrm{Rb}$ & $\mathrm{Sr}$ & Y & $\mathrm{Zr}$ & $\mathrm{Nb}$ & $\mathrm{Ba}$ & $\mathrm{Hf}$ & $\mathrm{Ta}$ & $\mathrm{Pb}$ & Th & $\mathrm{U}$ \\
\hline PCL-1 & 206.5 & 12.64 & 21.47 & 3652 & 8.33 & 12.9 & 56.1 & 14 & 1.89 & 10.3 & 13.3 & 5.22 & 10.4 & 0.64 & 41.84 & 0.3 & 0.05 & 7.516 & 0.81 & 0.25 \\
\hline PCL-2 & 1439.1 & 45.1 & 54.64 & 4104 & 54.4 & 58.7 & 50.4 & 64.4 & 7.08 & 5.02 & 31.7 & 17.4 & 77.6 & 5.55 & 207.2 & 2.3 & 0.46 & 33.4 & 5.54 & 0.89 \\
\hline PCL-3 & 695.4 & 16.31 & 10.86 & 3717 & 6.46 & 12 & 6.45 & 17.3 & 4.85 & 1.52 & 8.94 & 13.2 & 53.3 & 3.57 & 16.73 & 1.74 & 0.35 & 8.73 & 5.41 & 0.86 \\
\hline PCL-4 & 1451.9 & 20.24 & 26.19 & 5477 & 13.2 & 30.2 & 28.2 & 28.4 & 4.95 & 6.13 & 25.4 & 15.9 & 42.5 & 4.35 & 56.35 & 1.3 & 0.3 & & 4.65 & 0.97 \\
\hline PCL-5 & 3103.2 & 454.9 & 80.81 & 4573 & 27.3 & 86.3 & 38.3 & 95.9 & 12.3 & 51.3 & 79.1 & 51 & 162 & 10 & 243.9 & 4.04 & 0.79 & 57.49 & 9.06 & 2.78 \\
\hline PCL-6 & 2119 & 70.37 & 56.58 & 1639 & 28.5 & 52.8 & 113 & 43.5 & 7.21 & 1.94 & 22 & 14.9 & 104 & 4.87 & 15.56 & 3.46 & 0.58 & 5.39 & 8.03 & 1.06 \\
\hline PCL-7 & 585.6 & 82.41 & 13.46 & 7779 & 15.6 & 29.8 & 33.7 & 76.4 & 4.49 & 21.1 & 260 & 117 & 23.7 & 1.6 & 318 & 0.71 & 0.16 & 49.61 & 1.4 & 8.86 \\
\hline average & 1371.5 & 100.3 & 37.72 & 4420 & 22 & 40.4 & 46.5 & 48.6 & 6.12 & 13.9 & 62.9 & 33.5 & 67.6 & 4.37 & 128.5 & 1.98 & 0.38 & 27.02 & 4.99 & 2.24 \\
\hline REE & $\mathrm{La}$ & $\mathrm{Ce}$ & $\operatorname{Pr}$ & $\mathrm{Nd}$ & $\mathrm{Sm}$ & $\mathrm{Eu}$ & $\mathrm{Gd}$ & $\mathrm{Tb}$ & Dy & Ho & $\mathrm{Er}$ & $\mathrm{Tm}$ & $\mathrm{Yb}$ & $\mathrm{Lu}$ & & & & & & \\
\hline PCL-1 & 6.02 & 12.14 & 1.46 & 5.68 & 1.12 & 0.24 & 1.11 & 0.19 & 0.96 & 0.22 & 0.58 & 0.08 & 0.47 & 0.07 & & & & & & \\
\hline PCL-2 & 20.42 & 45.78 & 5.11 & 19.84 & 3.92 & 0.83 & 4.11 & 0.64 & 3.65 & 0.77 & 2.12 & 0.3 & 1.96 & 0.31 & & & & & & \\
\hline PCL-3 & 12.35 & 24.15 & 3.23 & 12.31 & 2.49 & 0.47 & 2.54 & 0.43 & 2.49 & 0.55 & 1.52 & 0.23 & 1.49 & 0.21 & & & & & & \\
\hline PCL-4 & 14.96 & 37.97 & 4.31 & 17.94 & 3.79 & 0.88 & 3.46 & 0.53 & 2.96 & 0.6 & 1.52 & 0.22 & 1.26 & 0.2 & & & & & & \\
\hline PCL-5 & 60.23 & 53.73 & 17.51 & 68.42 & 13.9 & 2.81 & 12.7 & 2.11 & 11.8 & 2.37 & 6.7 & 0.95 & 6.37 & 0.99 & & & & & & \\
\hline PCL-6 & 15.87 & 37.55 & 4.6 & 18.54 & 3.52 & 0.71 & 3.29 & 0.55 & 3.18 & 0.67 & 2 & 0.31 & 2.18 & 0.39 & & & & & & \\
\hline PCL-7 & 109.5 & 62.53 & 20.97 & 86.43 & 16.3 & 3.98 & 19.7 & 3.12 & 17.7 & 3.5 & 8.71 & 1.13 & 6.17 & 0.86 & & & & & & \\
\hline average & 34.19 & 39.12 & 8.17 & 32.74 & 6.43 & 1.42 & 6.7 & 1.08 & 6.1 & 1.24 & 3.31 & 0.46 & 2.84 & 0.43 & & & & & & \\
\hline
\end{tabular}

Table 5. REE ratios of Pengcuolin cherts

\begin{tabular}{|c|c|c|c|c|c|c|c|}
\hline sample & $\sum$ REE & LREE /HREE & $\mathrm{Ce} / \mathrm{Ce}^{*}$ & $\mathrm{Eu} / \mathrm{Eu} *$ & $(\mathrm{La} / \mathrm{Yb})_{\mathrm{N}}$ & $(\mathrm{La} / \mathrm{Ce})_{\mathrm{N}}$ & $(\mathrm{La} / \mathrm{Lu})_{\mathrm{N}}$ \\
\hline BCL-1 & 30.33 & 7.26 & 1 & 0.91 & 1.09 & 1 & 1.11 \\
\hline BCL-2 & 109.75 & 6.92 & 1.1 & 0.89 & 0.9 & 0.9 & 0.85 \\
\hline BCL-3 & 64.45 & 5.82 & 0.94 & 0.81 & 0.72 & 1.04 & 0.76 \\
\hline BCL-4 & 90.6 & 7.43 & 1.15 & 1.05 & 1.02 & 0.8 & 0.97 \\
\hline BCL-5 & 260.57 & 4.92 & 0.4 & 0.92 & 0.81 & 2.27 & 0.79 \\
\hline BCL-6 & 93.37 & 6.42 & 1.07 & 0.91 & 0.63 & 0.86 & 0.53 \\
\hline BCL-7 & 360.52 & 4.92 & 0.32 & 0.95 & 1.53 & 3.55 & 1.65 \\
\hline average & 144.23 & 6.24 & 0.85 & 0.92 & 0.96 & 1.49 & 0.95 \\
\hline
\end{tabular}

(Note: $\mathrm{Ce}^{*}$ is theoretical $\mathrm{Ce}$ value interpolated by $\mathrm{La}$ and $\mathrm{Pr}$ abundances, namely, $(\mathrm{La}+\mathrm{Pr}) / 2, \mathrm{Eu}^{*}$ is theoretical Eu value interpolated by $\mathrm{Sm}$ and $\mathrm{Gd}$ abundances, namely, $(\mathrm{Sm}+\mathrm{Gd}) / 2$, the subscript "N" stand for REE chondrite-normalized value) 


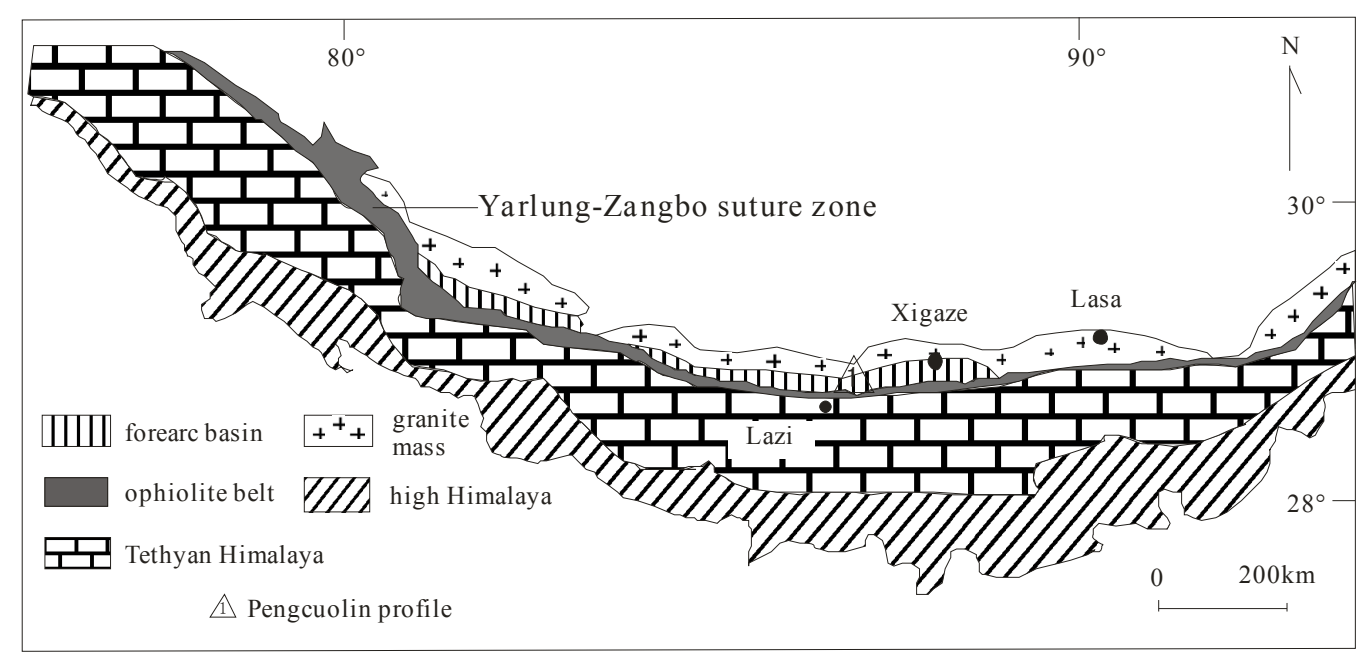

Figure 1. Profile location of Pengcuolin Chert (redrawn after WAN Xiaoqiao et al., 2003)
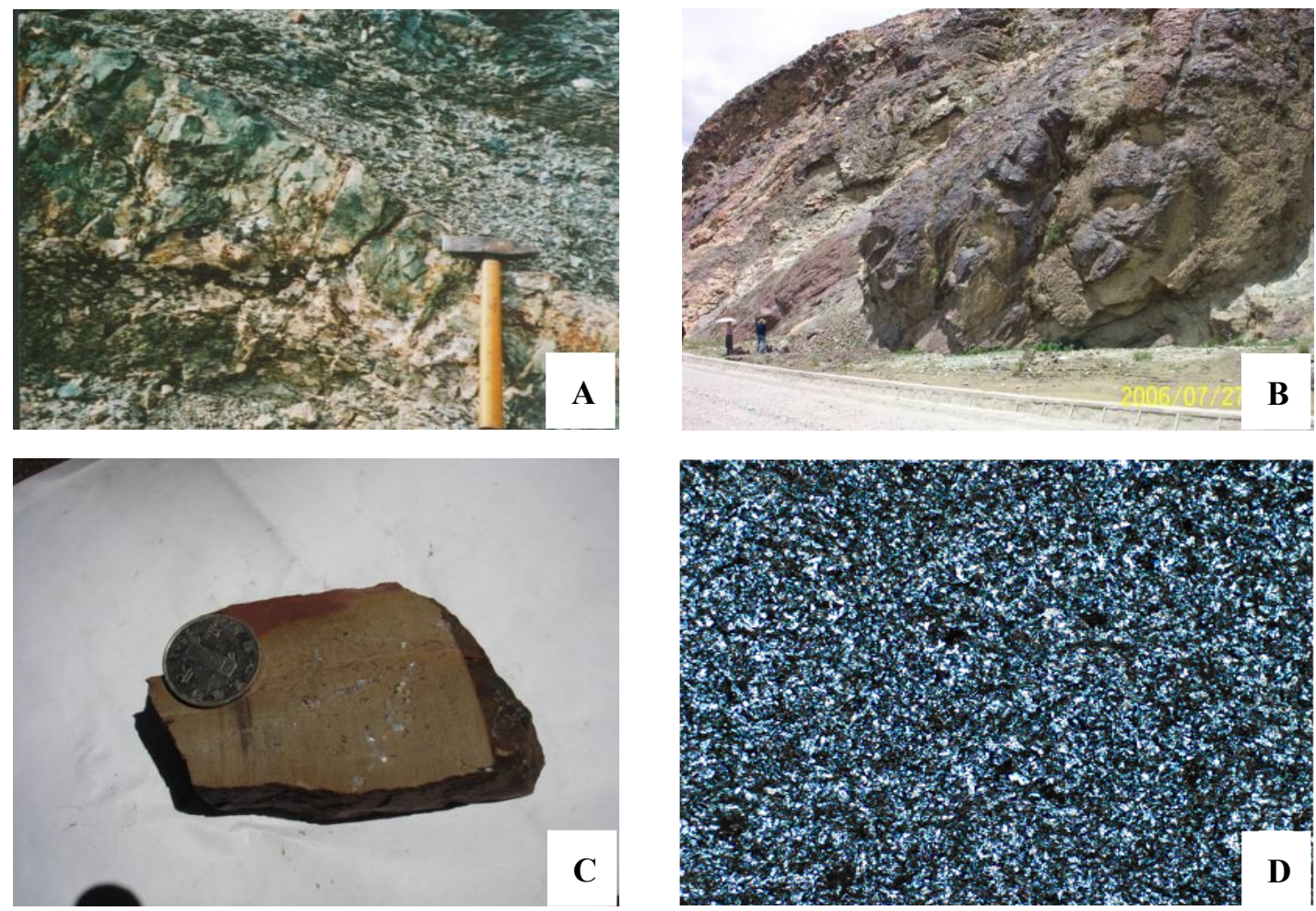

Figure 2. Field photos and microscope images of Pengcuolin chert 

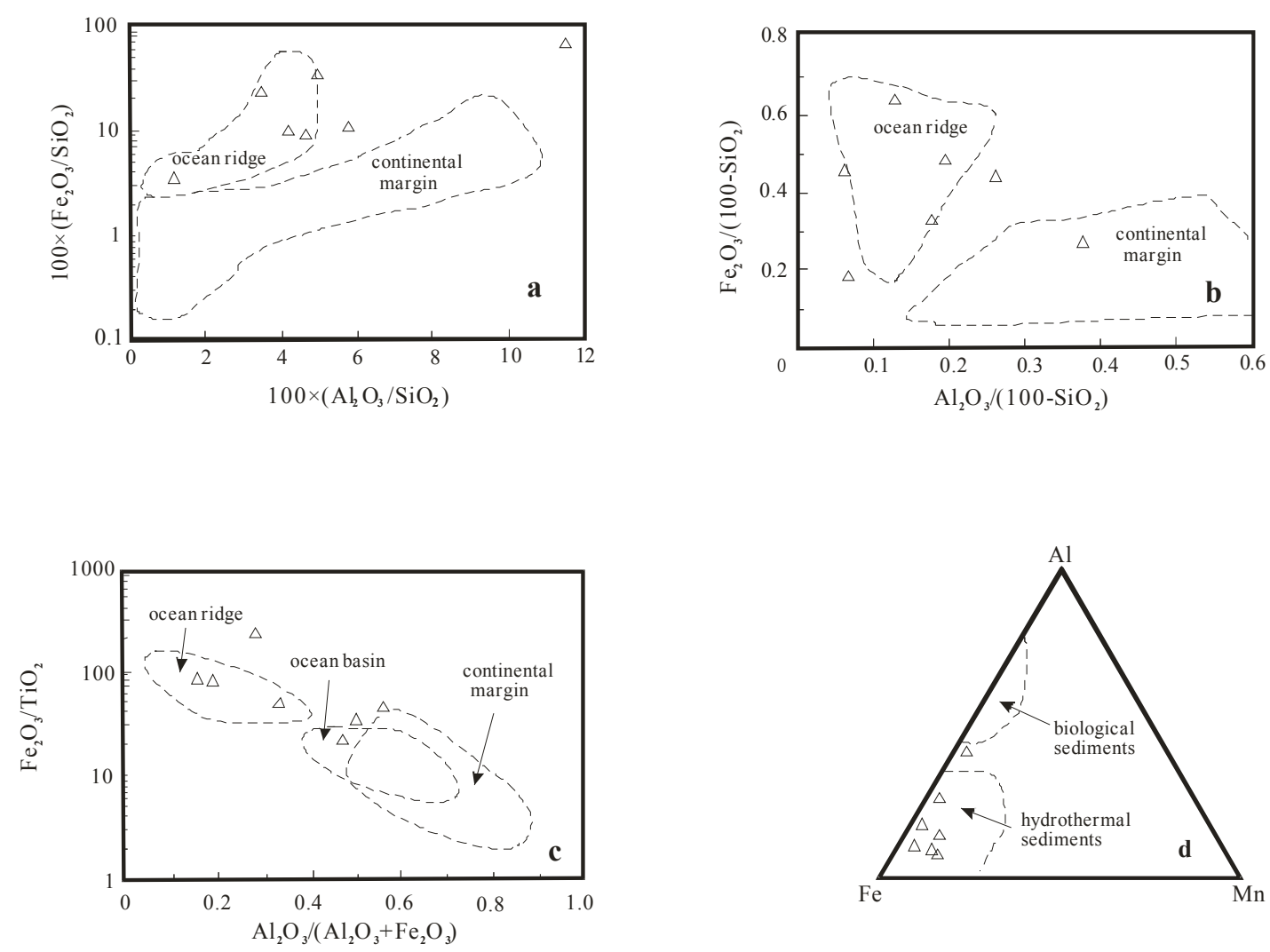

Figure 3. Major element diagrams of Pengcuolin cherts

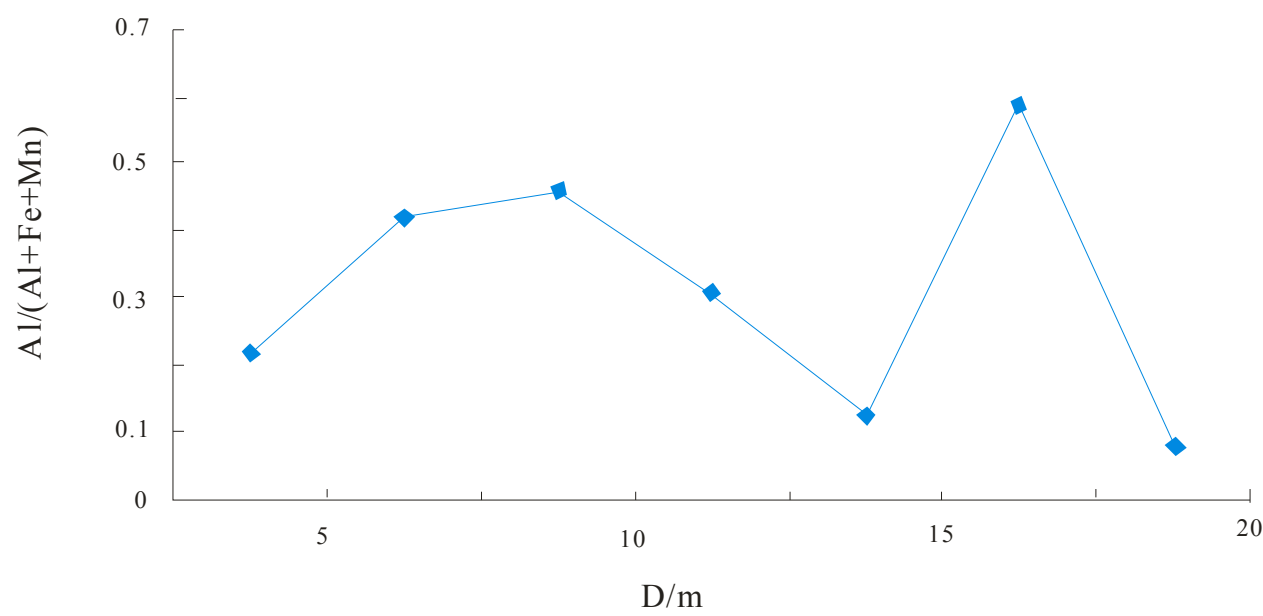

Figure 4. Partial variations of $\mathrm{Al} /(\mathrm{Al}+\mathrm{Mn}+\mathrm{Fe})$ in chert profile 


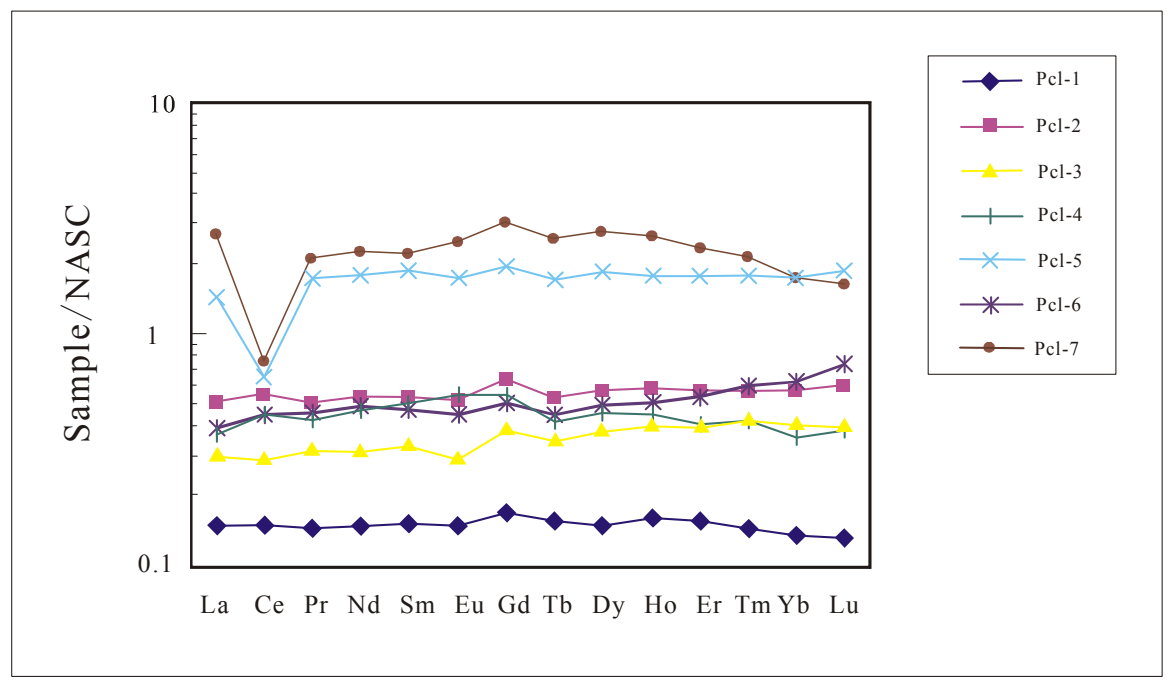

Figure 5. NASC-normalized REE distribution pattern of Pengcuolin cherts (Note: NASC-normalized REE stand for REE chondrite-normalized of North American Shale Composite)

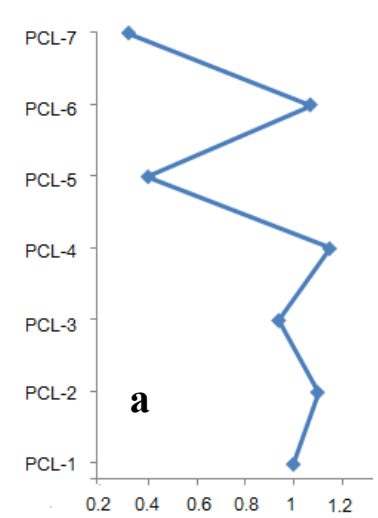

$\mathrm{Ce} / \mathrm{Ce}^{*}$

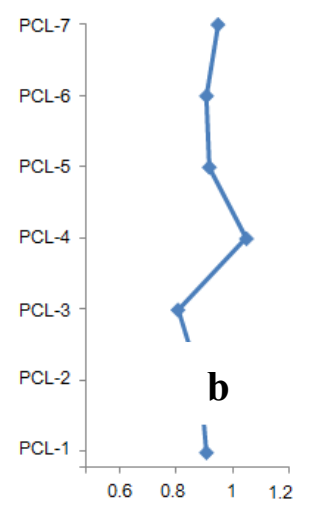

$\mathrm{Eu} / \mathrm{Eu}^{*}$

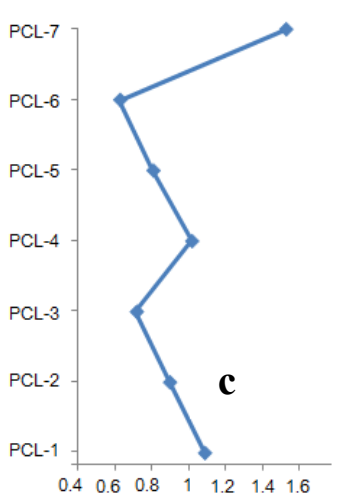

$(\mathrm{La} / \mathrm{Yb})_{\mathrm{N}}$

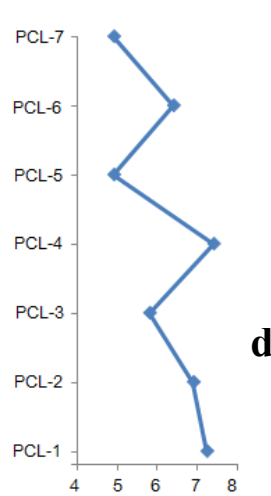

LREE /HREE

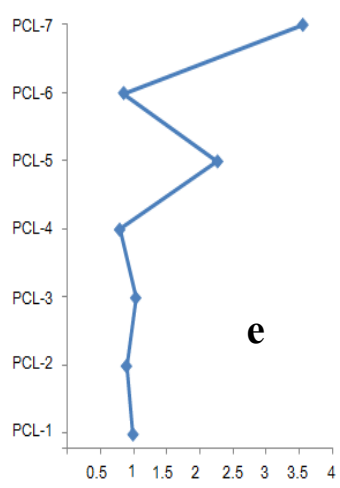

$(\mathrm{La} / \mathrm{Ce})_{\mathrm{N}}$

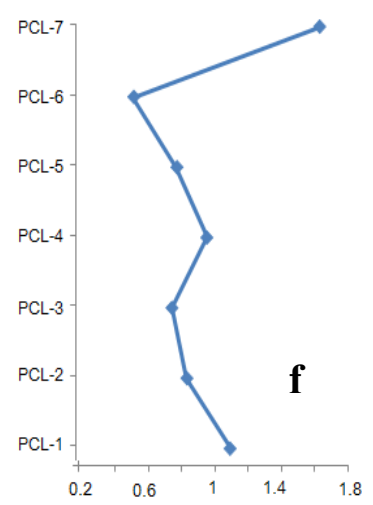

$(\mathrm{La} / \mathrm{Lu})_{\mathrm{N}}$

Figure 6. REE parameter variations of cherts 


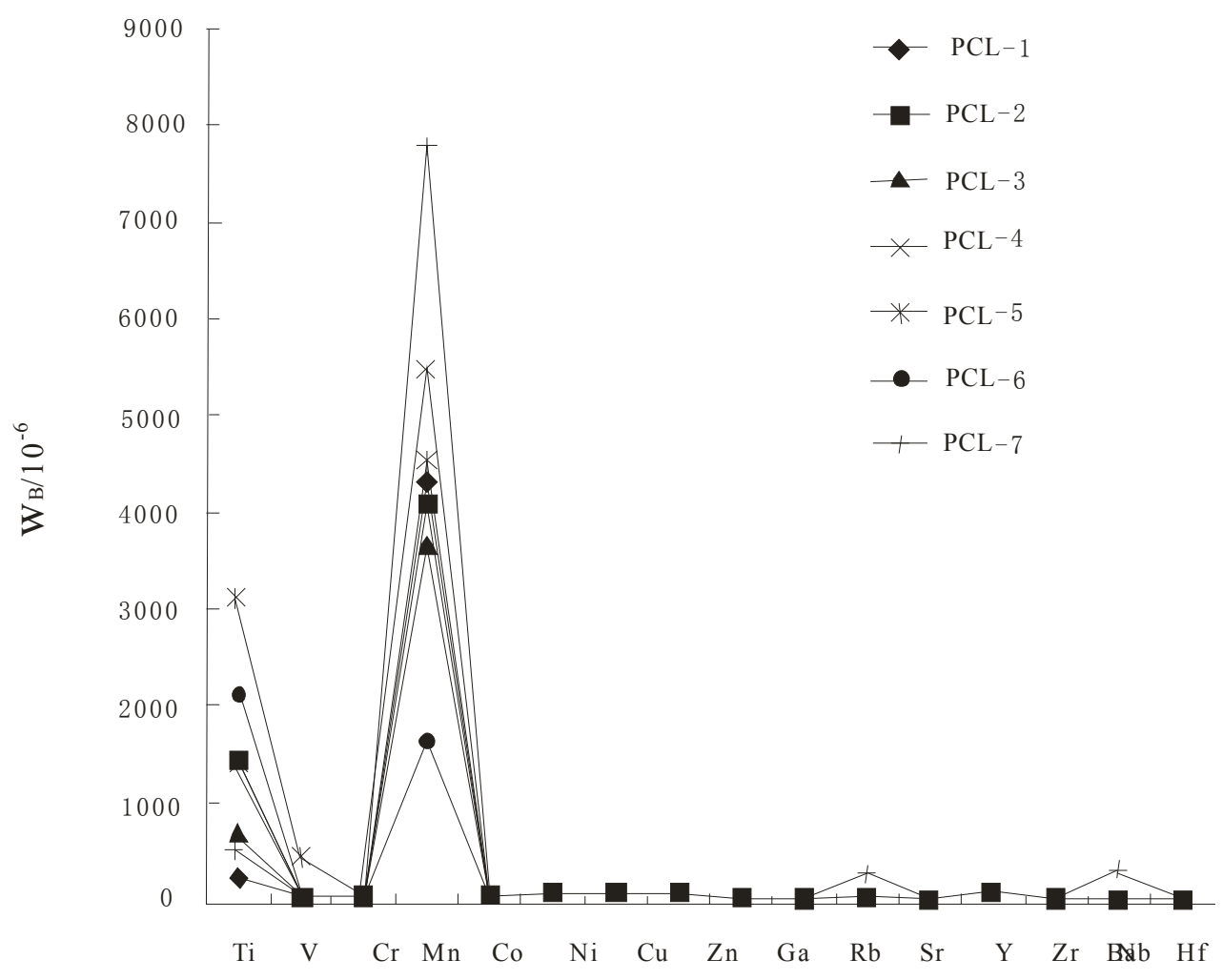

Figure 7. Spider distribution patterns of trace elements 